\title{
Growth, Yield and Water Use Effeciency of Forage Sorghum as Affected by Npk Fertilizer and Deficit Irrigation
}

\author{
Mohamed M. Hussein'1, Ashok K. Alva ${ }^{2}$ \\ ${ }^{1}$ Water Relations and Irrigation Department, National Research Centre, Cairo, Egypt \\ ${ }^{2}$ USDA-ARS, Prosser, WA, USA \\ Email: mmoursyhus@gmail.com, Ashok.Alva@ars.usda.gov
}

Received 8 May 2014; revised 7 June 2014; accepted 23 June 2014

Copyright (C) 2014 by authors and Scientific Research Publishing Inc.

This work is licensed under the Creative Commons Attribution International License (CC BY). http://creativecommons.org/licenses/by/4.0/

cc) (†) Open Access

\begin{abstract}
Drought stress (DS) is an important limiting factor for crop growth and production in some regions of the world. Limitation in water availability precludes optimal irrigation in some production regions. Therefore, investigations on the interaction of other factors to mitigate the DS to varying degree are important. Two field experiments were conducted in the experimental farm of the National Research Centre, Shalakan, Kalubia Governorate, Egypt, during 2004 and 2005 summer seasons to evaluate the interactions between $N, P, K$ rates and optimal vs. deficit irrigation regimes on biomass yield as well as water use efficiency (WUE) of forage sorghum. Omission of the 4th irrigation significantly decreased the biomass of sorghum c.v. Pioneer, as compared to that of the plants receiving optimal irrigation or subject to omission of the 2 nd irrigation. The biomass yield increased with an increase in NPK fertilizer rates. Plant height and leaf area also decreased by omitting the 2nd irrigation as compared to that of the plants under optimal irrigation, and further declined with omission of the 4th irrigation. The biomass of the plants (dry weight basis) that received the high $\mathrm{N}, \mathrm{P}, \mathrm{K}$ rates was greater by $26 \%, 29 \%$, and $35 \%$ as compared to that of the plants that received no $\mathrm{N}, \mathrm{P}, \mathrm{K}$ fertilizers, under optimal irrigation, omission of the $2 \mathrm{nd}$, and omission of the 4th irrigation, respectively. The corresponding increases in water use efficiency (based on fresh weight yield) were $37 \%, 42 \%$, and $55 \%$.
\end{abstract}

\section{Keywords}

Sorghum-Forage-Omitting of Irrigation-NPK Fertilizer-Growth, Yield-Water Use Efficiency

\section{Introduction}

Drought stress (DS) is the most important limiting factor for crop production in arid and semi-arid regions of the

How to cite this paper: Hussein, M.M. and Alva, A.K. (2014) Growth, Yield and Water Use Effeciency of Forage Sorghum as Affected by Npk Fertilizer and Deficit Irrigation. American Journal of Plant Sciences, 5, 2134-2140.

http://dx.doi.org/10.4236/ajps.2014.513225 
world. Severe DS during vegetative growth stage and moderate DS during flowering stage of grain sorghum crop contributed to about 30\% of reduction in grain yield, despite high water use efficiency [1]. New land used for cultivation of forage crops, including forage sorghum (Sorghum bicolor L.), are rather marginal in soil characteristics and productivity. Sustainable production can be achieved on these marginal soils only through use of cultivars tolerant to drought and salinity stress.

Forage sorghum is an important biomass crop for hay and silage [2]. Sorghum as a livestock feed is of significant importance, particularly in the tropical zone because of its adaptation to low fertility soils and other limiting factors, such as DS [3].

Mineral fertilizers play a vital role in improving crop yields but the major challenge is to ensure adequate balance between the different nutrients and support optimal yield. Current recommendations for producing optimal forage yields of sorghum-sudan grass hybrids suggest application of 50 to $100 \mathrm{~kg} \cdot \mathrm{N} \cdot \mathrm{ha}^{-1}$, applied in two equal doses at planting and after the first cut [4]. Timing and placement of $\mathrm{N}$ application should be managed to avoid significant losses while ensuring availability of adequate $\mathrm{N}$ when needed by the crop. Sorghum sudan grass is usually managed with low $\mathrm{N}$ fertilizer inputs $\left(\leq 80 \mathrm{~kg} \cdot \mathrm{ha}^{-1}\right)$ since growth and yield responses to $\mathrm{N}$ rates have been reported only up to $80 \mathrm{~kg} \cdot \mathrm{ha}^{-1}[5]$.

The optimum $\mathrm{P}$ availability is important for improving mineral $\mathrm{P}$ concentrations and yields of most crops [6] [7]. Soil solution P, following the dissolution of $\mathrm{P}$ fertilizers applied to the soil, is either taken up by the plants, precipitated, or adsorbed on the exchange sites in the soil [8]. Pholsen and Somsungnoen [9] reported an increase in most growth parameters of forage sorghum plants with an increase in $\mathrm{N}$ and $\mathrm{K}$ rates from 450 to 650

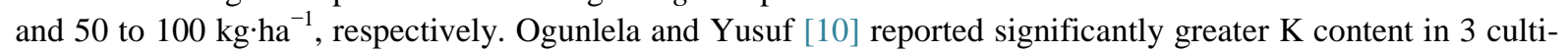
vars of forage sorghum with $75 \mathrm{~kg} \cdot \mathrm{ha}^{-1} \mathrm{~K}$ as compared to that of the plants receiving $25 \mathrm{or} 50 \mathrm{~kg} \cdot \mathrm{ha}^{-1} \mathrm{~K}$. Sharma and Kumari [11] reported that plant height, leaf area index, leaf area duration, plant growth rate, total dry matter production, $\mathrm{K}$ concentration and grain yield increased with $\mathrm{K}$ application rate from 25 to $50 \mathrm{~kg} \cdot \mathrm{ha}^{-1}$. Adequate availability of soil water and nutrients is important to support optimal plant growth and production in the arid and semi-arid regions [12]. Best management of nutrients is a successful strategy to alleviate abiotic stresses [13].

The objective of this study was to investigate the interactions between different rates of N, P, K and DS on growth, yield, and water use efficiency of forage sorghum.

\section{Material and Methods}

Two field experiments were conducted at the National Research Centre, Shalakan, Kalubia Governorate, Egypt, in 2004 and 2005 to evaluate the effects different rates of N, P, K fertilization on mitigating the adverse effects of DS on forage sorghum. The experiment comprised of factorial combination of 3 irrigation (main) and 4 fertilizer rates (sub) as shown below with 6 replications.

Irrigation treatments: Optimal irrigation (OI; No water stress), vs. two deficit irrigation (DI) treatments, i.e. omitting 2nd (DI-1) or 4th (DI-2) irrigation. The water uses for OI and DI treatments were 7960 and 6960 $\mathrm{m}^{3} \cdot \mathrm{ha}^{-1}$, respectively. Sub treatments were rates of N:P:K (in kg.ha $\left.{ }^{-1}\right) ; 0$ (0:0:0), 1 (36:8.4:32), 2 (72:16.8:64), 3 (144:33.6:28). Plot size was $3 \times 7 \mathrm{~m}$.

The full rates of $\mathrm{P}$ (as calcium super phosphate, $6.8 \% \mathrm{P}$ ) and $\mathrm{K}$ (as potassium sulfate, $40.3 \% \mathrm{~K}$ ), as per treatments, were broadcast and mixed with the soil during pre-plant tillage. Forage Sorghum (Sorghum bicolor (L.) Moench) cv. Pioneer was planted on July, 15th both years. The seed rate was $96 \mathrm{~kg} / \mathrm{ha}^{-1}$ in both seasons. Nitrogen rates, as per treatments, were applied as ammonium sulfate $(20.5 \% \mathrm{~N})$ in two equal doses; 21 and 35 days after sowing. The standard production practices for forage sorghum followed in the province were adapted (Recommendations of Egyptian Ministry of Agriculture, unpublished). The amount of each irrigation was 750 $\mathrm{m}^{3} \cdot \mathrm{ha}^{-1}$, except the irrigation after sowing was $1000 \mathrm{~m}^{3} \cdot \mathrm{ha}^{-1}$.

The following measurements were made on two plants from every subplot before cutting (Cutting was done 70 days after planting): Plant height $(\mathrm{cm})$; number of green leaves; leaf area; fresh and oven dry $\left(70^{\circ} \mathrm{C}\right.$ for three days) weights of stem and leaves.

Water Use Efficiency (WUE; $\mathrm{kg} \cdot \mathrm{m}^{-3}$ ) was calculated as marketable yield $(\mathrm{kg})$ per unit water use $\left(\mathrm{m}^{3}\right)$. Fresh and dry yields of forage per plot were measured and yield per ha was calculated.

Statistical significance of the treatments effects was evaluated by analysis of variance (ANOVA) test as described by [14]. 


\section{Results and Discussion}

Water stress i.e. omitting either the 2nd or 4th irrigation, significantly influenced plant height, leaf area, fresh weight of plant tops, and stem dry weight (Table 1). The negative effects of water stress were greater by omitting the 4th irrigation as compared to those by omitting the 2nd irrigation. Our results concur with those of Carmier et al. [15] who reported that irrigation influenced plant height and dry matter.

Mohammadkhani and Heidri [16] subjected the six-day-old seedlings to different concentrations of poly ethylene glycol (PEG) 6000 to induce drought stress treatment. After $24 \mathrm{~h}$ treatment in PEG 6000 the electrolyte leakage increased. Under drought stress the activities of protective enzymes in roots and shoots increased sharply. Drought induced by $40 \%$ concentration of PEG, which induced water potential of $1.76 \mathrm{MPa}$, which affected soluble sugars and proline content. The soluble sugars play an important role in the production of other compounds, energy, and stabilization of membranes [17], act as regulators of gene expression [18] and signal molecules [19]. Proline is important in water adjustment through stomatal aperture which, in turn, affects transpiration and photosynthesis [20]. Boomsma and Vyn [21] reported that water stress influenced plant uptake of water as well as nutrients. Li et al. [22] demonstrated that water stress impaired the oxidative defense systems in plants.

Omitting the 4th irrigation significantly decreased the fresh and dry yield of sorghum as compared to those of the plants grown under optimal irrigation or omitting the 2nd irrigation (Table 2). Li et al. [22] reported that sorghum yield affected by spatial or temporal stress from drought. Akmal and Jansenes [23] concluded that water deficit affected growth and yield of ryegrass. Ferre and Faci [24] demonstrated that deficit irrigation or reduced frequency of irrigation during the grain filling stage did not significantly affect the corn yield. They concluded that flowering stage was the most sensitive to water deficit as evident from significant reduction in biomass yield and harvest index due to water stress during flowering stage. They reported a linear relationship between amount of irrigation and grain yield.

Our study also revealed that WUE was greater for the plants subjected to omission of the 2nd irrigation than those of plants grown under optimal irrigation or omission of 4th irrigation (Table 2). The latter treatment resulted in the least WUE, both based on fresh or dry biomass weight. Ferre and Faci [24] reported that the negative impact of water deficit on WUE was greater when subjected to deficit irrigation during flowering stage than that during any other growth stages.

Table 1. Effects of drought stress on growth of sorghum plants (per plant basis; mean across 2004 and 2005 seasons).

\begin{tabular}{|c|c|c|c|c|c|c|c|c|c|}
\hline \multirow{2}{*}{ Irrigation } & \multirow{2}{*}{$\begin{array}{l}\text { Plant height } \\
\text { (cm) }\end{array}$} & \multirow{2}{*}{ No of Leaves } & \multirow{2}{*}{$\begin{array}{c}\text { Leaf area } \\
\left(\mathrm{cm}^{2}\right)\end{array}$} & \multicolumn{3}{|c|}{ Fresh weight (g) } & \multicolumn{3}{|c|}{ Dry weight (g) } \\
\hline & & & & Stem & Leaves & Total & Stem & Leaves & Total \\
\hline Optimal Irrigation & 113 & 4.7 & 3653 & 69.8 & 30.3 & 100.1 & 37.1 & 12.5 & 49.6 \\
\hline Omit 2nd irrigation & 92 & 4.4 & 2287 & 68.3 & 24.2 & 92.5 & 32.2 & 11.5 & 43.7 \\
\hline Omit 4th irrigation & 82 & 3.9 & 1808 & 40.3 & 20.3 & 60.6 & 17.5 & 9.9 & 27.4 \\
\hline $\operatorname{LSD}(\mathrm{P} \leq 0.05)$ & 6 & NS & 453 & 23.3 & 3.3 & 32.1 & 16.2 & NS & 22.3 \\
\hline
\end{tabular}

LSD = Least Significant Difference; NS = Non-Significant.

Table 2. Effects of drought stress on yield of sorghum and water use efficiency (WUE) (Mean across 2004 and 2005 seasons).

\begin{tabular}{ccccc}
\hline \multirow{2}{*}{ Irrigation } & Fresh yield $\left({\left.\mathrm{Mg} \cdot \mathrm{ha}^{-1}\right)}\right.$ & Dry yield $\left(\mathrm{Mg} \cdot \mathrm{ha}^{-1}\right)$ & \multicolumn{2}{c}{ WUE $\left(\mathrm{kg} \cdot \mathrm{m}^{-3}\right)$} \\
\cline { 2 - 5 } & & & Fresh wt basis & Dry wt basis \\
\hline Optimal Irrigation & 94.7 & 46.8 & 12.38 & 6.18 \\
Omit 2nd irrigation & 97.1 & 45.6 & 13.98 & 6.53 \\
Omit 4th irrigation & 81.7 & 36.8 & 11.68 & 5.28 \\
LSD (P $\leq 0.05)$ & 1.70 & 4.3 & $\mathrm{ND}$ & ND \\
\hline
\end{tabular}

LSD = Least Significant Difference; ND = LSD was not calculated. 
The increased rates of N, P, K increased the plant growth and biomass (Table 3). This trend is in agreement with those reported by Bokhtiar and Sakurai [25] on sugar cane; Bayu et al. [26] on sorghum; and Barros et al. [27] on intercropped maize/cowpea. Nitrogen is an important component of major structural, genetic, and metabolic compounds in plant cells, including chlorophyll, amino acids, ATP (adenosine triphosphate), and nucleic acids such as DNA [28]. Phosphorus is a vital component of: DNA, RNA, and ATP. Thus phosphorus is essential for the general health and vigor of all plants. Adequate P nutrition is critical for root development, increased stalk and stem strength, increased flowering and seed production, uniform and early crop maturity, improved crop quality, and increased resistance to plant diseases [28]. Potassium is important for various regulatory functions in plants. It is essential in nearly all processes needed to sustain plant growth and reproduction. Potassium plays a vital role in photosynthesis, translocation of photosynthates, protein synthesis, ionic balance, regulation of plant stomata and water use, activation of plant enzymes, and many other processes [28]. The forage yield at the highest N, P, K rates was $27 \%$ and $61 \%$ greater than that of the plants that received no N, P, K on fresh and dry weight basis, respectively (Table 4). The corresponding increases for the medium N, P, K rates were 8\% and $46 \%$.

Shrotriya [29] reported that balanced application of NPK caused up to $122 \%$ increase in sorghum yield in India. Increased plant growth with optimal N, P, K application provides vegetative cover, thus enhancing moisture retention, nutrient use efficiency and soil productivity [30]. Pholsen and Somsungnoen [9] reported that an increase in $\mathrm{N}$ and $\mathrm{K}$ rates significantly increased most growth parameters of sorghum plants. The highest total dry weight and seed yield were obtained from plants receiving 650 and $100 \mathrm{~kg} \cdot \mathrm{ha}^{-1} \mathrm{~N}$ and $\mathrm{K}$, respectively. Increased rates of N, P, K increased WUE (Table 4). Barros et al. [27] showed that WUE improved with increasing rate of nutrients.

The interaction between $\mathrm{N}, \mathrm{P}, \mathrm{K}$ rates and irrigation treatments was significant with respect to plant height, leaf area, total fresh weight and stem as well as total dry biomass weights (Table 5). The increases in leaf area at the highest N, P, K rates as compared to that of the plants receiving no N, P, K were $248 \%, 126 \%$, and $37 \%$ re-

Table 3. Effects of NPK rates on growth parameters of sorghum plants (per plant basis; mean across 2004 and 2005 seasons).

\begin{tabular}{|c|c|c|c|c|c|c|c|c|c|}
\hline \multirow{2}{*}{$\begin{array}{l}\text { Fertilizer } \\
\text { rates }\end{array}$} & \multirow{2}{*}{$\begin{array}{l}\text { Plant height } \\
\quad \text { (cm) }\end{array}$} & \multirow{2}{*}{ No of Leaves } & \multirow{2}{*}{$\begin{array}{c}\text { Leaf area } \\
\left(\mathrm{cm}^{2}\right)\end{array}$} & \multicolumn{3}{|c|}{ Fresh weight (g) } & \multicolumn{3}{|c|}{ Dry weight (g) } \\
\hline & & & & Stem & Leaves & Total & Stem & Leaves & Total \\
\hline 0 & 74 & 4.0 & 1512 & 42.3 & 18.0 & 60.3 & 21.8 & 8.8 & 30.6 \\
\hline 1 & 87 & 3.9 & 2191 & 58.3 & 23.5 & 81.8 & 26.8 & 10.8 & 37.7 \\
\hline 2 & 107 & 4.2 & 3015 & 62.2 & 28.3 & 90.5 & 30.8 & 12.4 & 33.2 \\
\hline 3 & 115 & 5.0 & 3616 & 75.5 & 31.4 & 106.8 & 36.3 & 13.1 & 49.4 \\
\hline $\operatorname{LSD}(\mathrm{P} \leq 0.05)$ & 5 & 1.0 & 328 & 5.6 & 3.2 & 6.2 & 4.3 & 2.9 & 4.6 \\
\hline
\end{tabular}

LSD = Least Significant Difference; N:P:K Rates $\left(\mathrm{kg} \cdot \mathrm{ha}^{-1}\right) ; 0$ = None; 1 = 36:8.4:32; 2 = 72:16.8:64; 3 = 144:33.6:128.

Table 4. Effects of NPK rates on yield of sorghum and water use efficiency (WUE) (mean across 2004 and 2005 seasons).

\begin{tabular}{|c|c|c|c|c|}
\hline \multirow{2}{*}{$\begin{array}{l}\text { Fertilizer } \\
\text { rates }\end{array}$} & \multirow[t]{2}{*}{ Fresh yield $\left(\mathrm{Mg} \cdot \mathrm{ha}^{-1}\right)$} & \multirow[t]{2}{*}{ 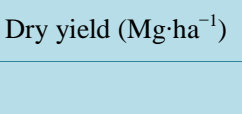 } & \multicolumn{2}{|c|}{ WUE $\left(\mathrm{kg} \cdot \mathrm{m}^{-3}\right)$} \\
\hline & & & Fresh wt basis & Dry wt basis \\
\hline 0 & 86 & 30.9 & 10.50 & 5.30 \\
\hline 1 & 87 & 38.7 & 12.07 & 5.50 \\
\hline 2 & 93 & 45.2 & 13.00 & 6.30 \\
\hline 3 & 109 & 49.7 & 15.13 & 6.87 \\
\hline $\operatorname{LSD}(\mathrm{P} \leq 0.05)$ & 0.50 & 0.53 & ND & ND \\
\hline
\end{tabular}

LSD = Least Significant Difference; ND = LSD was not calculated; N:P:K Rates $\left(\mathrm{kg}^{\prime} \mathrm{ha}^{-1}\right) .0=$ None; 1 = 36:8.4:32; 2= 72:16.8:64; $3=144: 33.6: 128$. 
spectively in optimal irrigation, omission of the 2nd, and omission of the 4th irrigation treatments, respectively. The corresponding increases in total fresh weight were $98 \%, 67 \%$, and $67 \%$.

The interaction of effects of irrigation and NPK fertilizer on yield was significant only on dry biomass yield (Table 6). The increases in biomass yield at the highest N, P, K rates as compared to that of plants receiving no N, $\mathrm{P}$, K were $26 \%, 29 \%$, and $35 \%$, respectively, at optimal irrigation, omission of the $2 \mathrm{nd}$, and omission of the 4 th

Table 5. Effects of drought stress and N, P, K rates on growth of forage sorghum plants (per plant basis; average of two seasons).

\begin{tabular}{|c|c|c|c|c|c|c|c|c|c|c|}
\hline \multirow{2}{*}{ Irrigation } & \multirow{2}{*}{$\begin{array}{c}\text { Fertilizer } \\
\text { rates }\end{array}$} & \multirow{2}{*}{$\begin{array}{l}\text { Plant height } \\
\text { (cm) }\end{array}$} & \multirow{2}{*}{ No of Leaves } & \multirow{2}{*}{$\begin{array}{c}\text { Leaf Area } \\
\left(\mathrm{cm}^{2}\right)\end{array}$} & \multicolumn{3}{|c|}{ Fresh weight (g) } & \multicolumn{3}{|c|}{ Dry weight (g) } \\
\hline & & & & & Stem & Leaves & Total & Stem & Leaves & Total \\
\hline \multirow{5}{*}{$\begin{array}{l}\text { Optimal } \\
\text { Irrigation }\end{array}$} & 0 & 80 & 4.2 & 1537 & 46.3 & 19.0 & 65.3 & 25.0 & 9.5 & 34.5 \\
\hline & 1 & 108 & 4.4 & 3201 & 69.8 & 29.8 & 99.6 & 37.3 & 11.7 & 49.0 \\
\hline & 2 & 127 & 4.7 & 4500 & 72.3 & 34.5 & 106.8 & 38.8 & 13.7 & 52.5 \\
\hline & 3 & 137 & 5.3 & 5354 & 90.7 & 38.0 & 128.7 & 47.1 & 15.0 & 62.1 \\
\hline & 0 & 73 & 4.1 & 1479 & 50.3 & 18.8 & 69.1 & 25.6 & 10.0 & 35.6 \\
\hline \multirow{3}{*}{ Omit 2nd irrigation } & 1 & 88 & 3.9 & 1796 & 67.3 & 21.5 & 88.8 & 27.0 & 10.8 & 37.8 \\
\hline & 2 & 103 & 4.2 & 2613 & 72.2 & 25.3 & 97.5 & 34.5 & 12.5 & 47.0 \\
\hline & 3 & 110 & 5.3 & 3348 & 83.5 & 31.0 & 114.5 & 41.5 & 12.5 & 54.0 \\
\hline \multirow{4}{*}{ Omit 4th irrigation } & 0 & 68 & 3.8 & 1569 & 20.2 & 16.3 & 46.5 & 14.6 & 7.0 & 21.6 \\
\hline & 1 & 72 & 3.4 & 1576 & 37.8 & 19.3 & 57.1 & 16.2 & 10.0 & 26.1 \\
\hline & 2 & 91 & 3.8 & 1943 & 42.0 & 21.2 & 63.2 & 19.1 & 11.0 & 30.1 \\
\hline & 3 & 98 & 4.5 & 2145 & 51.2 & 25.2 & 76.4 & 20.1 & 11.7 & 31.8 \\
\hline $\operatorname{LSD}(\mathrm{P} \leq 0.05)$ & & 8 & NS & 567 & NS & NS & 10.8 & 7.7 & NS & 8.0 \\
\hline
\end{tabular}

LSD = Least Significant Difference; NS = Non-Significant; N:P:K Rates $\left(\mathrm{kg}^{\prime} \mathrm{ha}^{-1}\right) .0$ = None; 1 = 36:8.4:32; 2 = 72:16.8:64; 3 = 144:33.6:128.

Table 6. Effects of drought stress and N, P, K, rates on yield of forage sorghum and water use efficiency (WUE).

\begin{tabular}{|c|c|c|c|c|c|}
\hline \multirow{2}{*}{ Irrigation } & \multirow{2}{*}{ Fertilizer } & \multirow[t]{2}{*}{ 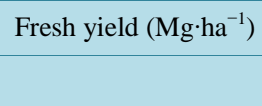 } & \multirow[t]{2}{*}{ Dry yield $\left(\mathrm{Mg} \cdot \mathrm{ha}^{-1}\right)$} & \multicolumn{2}{|c|}{ WUE $\left(\mathrm{kg} \cdot \mathrm{m}^{-3}\right)$} \\
\hline & & & & Fresh wt basis & Dry wt basis \\
\hline \multirow{5}{*}{ Optimal irrigation } & 0 & 80 & 42 & 10.5 & 5.5 \\
\hline & 1 & 91 & 45 & 11.9 & 5.9 \\
\hline & 2 & 97 & 48 & 12.7 & 6.3 \\
\hline & 3 & 110 & 53 & 14.4 & 7.0 \\
\hline & 0 & 80 & 41 & 11.5 & 5.9 \\
\hline \multirow{3}{*}{ Omit 2nd irrigation } & 1 & 93 & 39 & 13.4 & 5.6 \\
\hline & 2 & 102 & 49 & 14.7 & 7.0 \\
\hline & 3 & 113 & 53 & 16.3 & 7.6 \\
\hline \multirow{4}{*}{ Omit 4th irrigation } & 0 & 66 & 31 & 9.5 & 4.5 \\
\hline & 1 & 76 & 35 & 10.9 & 5.0 \\
\hline & 2 & 81 & 39 & 11.6 & 5.6 \\
\hline & 3 & 102 & 42 & 14.7 & 6.0 \\
\hline LSD at $5 \%$ & & NS & 0.9 & ND & ND \\
\hline
\end{tabular}

LSD = Least Significant Difference; ND = LSD was not calculated; NS = Non-Significant; N:P:K Rates $\left(\mathrm{kg} \cdot \mathrm{ha}^{-1}\right) ; 0=$ None; $1=36: 8.4: 32 ; 2=$ $72: 16.8: 64 ; 3=144: 33.6: 128$. 
irrigations. The results support that the beneficial effects of optimal N, P, K fertilizer was greater under increased DS.

Soil nutrient availability induces large changes in plant functional attributes, which affect the water and carbon economy of plants [31]. In particular, nitrogen $(\mathrm{N})$ can affect the cold and drought tolerance, yet there is no clear consensus on the magnitude or direction of its effect. Low tissue $\mathrm{N}$ concentration may hinder either cold or drought hardening [32]. Proper available nitrogen in soils enhanced the growth of plants and lowered the adverse effect on growth caused by water stress [33].

Water use efficiency also responded favorably to increased rates of N, P, K (Table 6). The WUE was greater for omission of the 2nd irrigation as compared to that of the plants under optimal irrigation or omission of the 4th irrigation. The WUE (fresh weight basis) for the plants which received high rates of N, P, K as compared to those of the plants received no N, P, K were greater by 55\%, 42\%, and 37\%, respectively, for omission of the 4th irrigation, the 2nd irrigation, and optimal irrigation. The corresponding increases on dry weight basis were $33 \%$, 29\%, and 27\%. Therefore, the WUE response to N, P, K fertilizer was greater with severity of water stress.

\section{References}

[1] Khalili, I. Akbari, N. and Chaichi, M.R. (2008) Limited Lrrigation and Phosphorus Fertilizer Effects on Yield and Yield Components of Grain Sorghum (Sorghum bicolor L.var. Kimia). American-Eurasian Journal of Agricultural \& Environmental Science, 3, 697-702.

[2] Skerman, P.J. and Rivers, F. (1999) Tropical Grasses. FAO. Plant Production and Protection, Series No. 23, FAO, Rome.

[3] Pholsen, S. and Suksri. A. (2007) Effects of Phosphorus and Potassium on Growth, Yield and Fodder Quality of IS 23585 Forage Sorghum Cultivar (Sorghum bicolor L.). Pakistan Journal of Biological Sciences, 10, 1604-1610. http://dx.doi.org/10.3923/pjbs.2007.1604.1610

[4] Ontario Ministry of Agriculture and Food (OMAF) (2002) Annual Report.

[5] Ram, S.N. and Singh, B. (2001) Effect of Nitrogen and Harvesting Time on Yield and Quality of Sorghum (Sorghum bicolor) Intercropped with Legumes. Indian Journal of Agronomy, 46, 32-37.

[6] Cisar, G.D., Synder, G.H. and Swanson, G.S. (1992) Nitrogen, P and K Fertilization for Histosols Grown St. Augustine Grass Sod. Agronomy Journal, 84, 475-479. http://dx.doi.org/10.2134/agronj1992.00021962008400030023x

[7] Halliday, D.T. and Trenkel, M.E. (1992) World Fertilizer Use Manual. International Fertilizer Industry Association, Paris, 31-32.

[8] Rashid, M., Ranjha, M. and Rehim, A. (2007) Model Based P Fertilization to Improve Yield and Quality of Sorghum (Sorghum bicolor L.) Fodder on an Ustochrept Soil. Pakistan Journal of Agricultural Sciences, 44, 221-227.

[9] Pholsen, S. and Sormsungnoen, N. (2005) Effects of Nitrogen and Potassium Rates and Planting Distances on Growth, Yield and Fodder Quality of a Forage Sorghum (Sorghum bicolor L. Moench). Pakistan Journal of Biological Sciences, 7, 1793-1800.

[10] Ogunlela, B. and Yusuf, Y. (1988) Yield and Growth Response to Potassium of Grain Sorghum as Influenced by Variety in a Savanna Soil of Nigeria. Fertilizer Research, 16, 217-226.

[11] Sharma, P.S. and Kumari, T.S. (1996) Effect of Potassium under Water Stress on Growth and Yield of Sorghum in Vertisol. J. Potash. Res., 12, 319-325.

[12] Richards, A.R. (2006) Physiological Traits Used in the Breeding of New Cultivars for Water Scarce Environments. Agricultural Water Management, 80, 197-211. http://dx.doi.org/10.1016/j.agwat.2005.07.013

[13] Aulakh, M.S. and Malhi, S.S. (2004) Interaction of Nitrogen with Other Nutrients and Water: Effects on Crop Yield and Quality, Nutrient Use Efficiency, Carbon Sequestration and Environmental Pollution. Advances in Agronomy, 86, 341-409. http://dx.doi.org/10.1016/S0065-2113(05)86007-9

[14] Snedecor, G.W. and Cochran, W.G. (1990) Statistical Methods. 8th Edition, Iowa State University, Iowa.

[15] Carmier, A., Aharoni, Y., Edelstein, M., Umiel, N., Hagiladi, A., Yousef, E., Nikbachat, M., Zenou, A. and Miron, J. (2006) Effects of Irrigation and Plant Density on Yield, Composition and in Vitro Digestibility of a New Forage Sorghum Variety, TAL, at Two Maturity Stage. Animal Feed Science and Technology, 131, 121-133. http://dx.doi.org/10.1016/j.anifeedsci.2006.02.005

[16] Mohammadkhani, N. and Heidri, R. (2008) Effects of Drought Stress on Soluble Proteins in Two Maize Varieties. Turkish Journal of Biology, 32, 23-30.

[17] Hoekstra, F.A., Golovinia, E.A. and Butinik, J. (2001) Mechanisms of Plant Desiccation Tolerance. Trends in Plant Science, 6, 431-438. http://dx.doi.org/10.1016/S1360-1385(01)02052-0 
[18] Koch, K.E. (1996) Carbohydrate-Modulated Gene Expression in Plants. Annual Review of Plant Physiology and Plant Molecular Biology, 47, 509-540. http://dx.doi.org/10.1146/annurev.arplant.47.1.509

[19] Smeekens, S. (2000) Sugar-Induced Signal Transduction in Plants. Annual Review of Plant Physiology and Plant Molecular Biology, 51, 49-81. http://dx.doi.org/10.1146/annurev.arplant.51.1.49

[20] Larher, F., Leport, L., Petrelavisky, M. and Chapart, M. (1993) Effects of Osmo Induced Proline Response in Higher Plants. Plant Physiology and Biochemistry, 31, 911-922.

[21] Boomsma, C.R. and Vyn, T.J. (2008) Maize Drought Tolerance: Potential Improvements through Arbuscular Mycorrhizal Symbiosis. Field Crops Research, 108, 14-31. http://dx.doi.org/10.1016/j.fcr.2008.03.002

[22] Li, K.R., Wang, H.H., Han, G., Wang, Q.J. and Fan, J. (2008) Effects of Brassinolide on the Survival, Growth and Drought Resistance of Robinia pseudoacacia Seedlings under Water-Stress. New Forests, 35, 255-266.

[23] Akmal, M. and Janssens, J.J. (2004) Productivity and Light Use Efficiency of Perennial Ryegrass with Contrasting Water and Nitrogen Supplies. Field Crop Research, 88, 143-155. http://dx.doi.org/10.1016/j.fcr.2003.12.004

[24] Ferré, I. and Faci, J.M. (2009) Deficit Irrigation in Maize for Reducing Agricultural Water in a Mediterranean Environment. Agricultural Water Management, 96, 383-394. http://dx.doi.org/10.1016/j.agwat.2008.07.002

[25] Bokhtiar, S.M. and Sakurai, K. (2005) Effect of Application of Inorganic and Organic Fertilizers on Growth, Yield and Quality of Sugarcane. Sugar Tech, 7, 35-37. http://dx.doi.org/10.1007/BF02942415

[26] Bayu, W., Rethman, N.F.G., Hammes, P.S. and Alemu, G. (2006) Effects of Farmyard Manure and Inorganic Fertilizers on Sorghum Growth, Yield, and Nitrogen Use in a Semi-Arid Area of Ethiopia. Journal of Plant Nutrition, 29, 391407. http://dx.doi.org/10.1080/01904160500320962

[27] Barros, I., Gaiser, T., Lange, F.M. and Römheld, V. (2007) Mineral Nutrition and Water Use Patterns of a Maize/Cowpea Intercrop on a Highly Acidic Soil of the Tropic Semiarid. Field Crops Research, 101, 26-36. http://dx.doi.org/10.1016/j.fcr.2006.09.005

[28] Marschner, H. (1995) Mineral Nutrition of Higher Plants. 2nd Edition, Acadmic Press, London.

[29] Shrotriya, G.C. (1998) Balanced Fertilizer-India Experience. Proceedings of Symposium on Plant Nutrition Management for Sustainable Agricultural Growth, NFDC, 8-10 December 1997, Islamabad.

[30] Bumb, B.I. and Bannante, C.A. (1996) The Use of Fertilizer in Sustaining Food Security and Protecting the Environment-2020. Proceedings of Conference on Agriculture and Fertilizer Use by 2010, NEDC, Islamabad, 35.

[31] Salifu, K.F. and Timmer, V.R. (2003) Nitrogen Retranslocation Response of Young Picea mariana to Nitrogen-15 Supply. Soil Science Society of America Journal, 67, 309-317. http://dx.doi.org/10.2136/sssaj2003.0309

[32] Andivia, E., Fernández, M. and Vázquez-Piqué, J. (2011) Autumn Fertilization of Quercus ilex ssp. ballota (Desf.) Samp. Nursery Seedlings: Effects on Morpho-Physiology and Field Performance. Annals of Forest Science, 68, 543553. http://dx.doi.org/10.1007/s13595-011-0048-4

[33] Villar-Salvador, P., Peñuelas, J.L. and Jacobs, D.F. (2013) Nitrogen Nutrition and Drought Hardening Exert Opposite Effects on the Stress Tolerance of Pinus pinea L. Seedlings. Oxford Journals Life Sciences Tree Physiology, 33, 221232. 
Scientific Research Publishing (SCIRP) is one of the largest Open Access journal publishers. It is currently publishing more than 200 open access, online, peer-reviewed journals covering a wide range of academic disciplines. SCIRP serves the worldwide academic communities and contributes to the progress and application of science with its publication.

Other selected journals from SCIRP are listed as below. Submit your manuscript to us via either submit@scirp.org or Online Submission Portal.
